Open Access

\title{
The role of problem solving ability on innovative behavior and opportunity recognition in university students
}

\author{
Ji Young Kim ${ }^{1}$, Dae Soo Choi ${ }^{1}$, Chang-Soo Sung ${ }^{1}$ and Joo Y. Park ${ }^{2^{*}}$
}

\author{
* Correspondence: park3500@naver. \\ com \\ ${ }^{2}$ Yonsei School of Business, Yonsei \\ University, 50 Yonsei-ro, \\ Seodaemun-gu, Seoul 120-749, \\ South Korea \\ Full list of author information is \\ available at the end of the article
}

\begin{abstract}
Universities engage in entrepreneurship education to increase social value creation, through students' new opportunities recognition. However, there are not enough of empirical researches on whether the current entrepreneurship education can be differentiated from other curriculum to improve the opportunity recognition process. This study argues that it is very important for cognitive abilities to be manifested as behavior when students in university are new opportunities recognition. For this purpose, the relationship between problem solving ability, innovation behavior, and opportunity perception was verified empirically. This study was conducted on 203 students who took entrepreneurship education courses at Korean universities. The results of this study showed that problem solving ability positively influenced innovation behavior and opportunity perception. Innovation behavior was identified as a key parameter that partially mediated the relationship between problem solving ability and innovation behavior. The implication of this study is to prove the relationship between individual 's problem - solving ability considering the characteristics of education in Korea and the opportunity through innovative behavior and various learning strategies to help entrepreneurship education to design better courses for the future It has important implications for strategic pedagogy that can enhance behavioral elements in development.
\end{abstract}

Keywords: Problem-solving ability, Innovative behavior, Opportunity recognition, Entrepreneurship education

\section{Background}

It is the new opportunity recognition that all firms focus on for a new economic paradigm (Ancona and Caldwell, 1992). Recognizing high opportunities can significantly improve profit, growth, and / or competitive positioning. And this new opportunity leads to innovation. From a conceptual point of view, research is continuing on the question of 'what is opportunity' and 'where is opportunity' (Gartner and Carter, 2003; Venkataraman \& Sarasvathy, 2001). Research on the discovery and realization of new opportunities is a very important research area that suggests how to discover and utilize creative opportunities that create new value and profit for pre-service workers, and is the ultimate goal of entrepreneurship education. (Kim et al., 2016). Particularly, there is a lot of debate about the relationship between opportunity perception and personal characteristics. Despite many arguments, however, research on individual

(c) The Author(s). 2018 Open Access This article is distributed under the terms of the Creative Commons Attribution 4.0 International License (http://creativecommons.org/licenses/by/4.0/), which permits unrestricted use, distribution, and reproduction in any medium, provided you give appropriate credit to the original author(s) and the source, provide a link to the Creative Commons license, and indicate if changes were made. 
characteristics and opportunity perceptions is still insufficient, and a unified opinion has not been created due to differences between cognitive and behavioral theories (Ko \& Butler, 2003). In particular, there is much controversy over the relationship between opportunity recognition and personal traits, and research has been continuing to demonstrate that organizational learning in organizations can influence opportunity recognition (Shane \& Venkataraman, 2000). In particular, learning enhances cognitive ability, which is an opportunity that leads to opportunity recognition through the manifestation of behavior (Lumpkin and Dess, 2004). Many studies have also demonstrated the difference in behavior that successful entrepreneurs see as contributing to their ability to recognize opportunities and create innovative business ideas (Dyer et al., 2008; Kim et al., 2017). For example, Alvarez and Barney (2005) argue for mountain climbing and mountain building to understand the implications of entrepreneurial behavior in relation to these theories. In other words, a new opportunity for entrepreneurs is not a passive case that is generally found and climbed by climbers such as mountains, but rather by the actions of entrepreneurs, creating competition for the market, creating another market, Is the same. Therefore, in order for a person's cognitive ability to recognize a new opportunity, it must focus on manifesting an action that can realize an innovative idea. In this regard, Kanter (1988) proved the relationship between new opportunity recognition and those with innovative tendencies and regarded this new opportunity recognition as innovation activity through organizational education. Scott and Bruce (1994) have integrated a number of research flows into innovation pioneers to develop and test individual innovative behavioral models. In particular, they argued that individual problem-solving styles are very important to induce innovative behavior. Although there are a number of studies on problem solving ability, innovation behavior, and new opportunities, most of the opportunistic researches have been conducted in organizational units of companies. Is still insufficient. Furthermore, unified opinions were not created due to differences between cognitive theory and behavioral theory (Ko \& Butler, 2003). It is also true that the effects of entrepreneurship education in university have not been studied empirically because they are mainly focused on promoting cognitive ability and applied to various kinds of teaching methods.

This study argues that it is very important for cognitive abilities to be manifested as behavior that. "Through" courses, In other words, it is very important to induce students to act through 'learning through process' learning through behavioral learning by providing students with some (virtual or real) business to start doing some of the actions of the entrepreneur. When students in university are new opportunity recognition. Especially, entrepreneurship education, which ultimately focuses on whether it is a new opportunity, is very important to induce behavior through behavior learning beyond the cognitive ability as the general education curriculum. Particularly, innovative behaviors that create and realize innovative ideas are very important for new opportunity recognition (Paine \& Organ, 2000).In order to achieve this, various kinds of teaching methods are being pursued in the university, but studies on the effectiveness of behavioral learning have not been studied yet. In this study, we are based on team-based learning among various teaching methods for behavior learning that leads to innovative behaviors. Team learning instructional activity sequence designed by 
Michaelsen and Sweet (2008), the most well known team-based learning in entrepreneurship education as in class-primarily group work and outside classprimarily individual work. In this way, we demonstrate empirically the relationship between individual problem solving ability and opportunity through innovative behavior, and develop a variety of learning strategies that help entrepreneurship education to design better courses for the future. I would like to point out some implications for strategic pedagogy to increase the element.

The paper proceeds as follows: Initially we present the theory of innovative behavior with individual problem-solving ability, innovative behavior and opportunity recognition. We develop hypotheses to confirm its basic predictions in the student context. Finally, we link the findings with the wider social effect of entrepreneurship literature and highlight the theoretical contributions and practical implications.

\section{Theoretical background}

\section{'Opportunity recognition' as entrepreneurship education unit of analysis}

A commonly focused analysis in entrepreneurship research over the last 30 years has been the 'opportunity', most simply defined as any situation in which new products or services can be development of production (Casson, 1982; Shane \& Venkataraman, 2000; Venkataraman, 1997). The definition of opportunity recognition is defined in many ways, but opportunity is defined as a perceived means of generating economic value (ie, profit) that has not been exploited previously and is not currently exploited by others. If opportunity is defined in this way, opportunity recognition can be defined as a cognitive process (or process) that concludes that an individual has identified an opportunity (Baron and Ensley, 2006). Kirzner (1997) pointed out that the distribution of information in society affects the discovery of entrepreneurial opportunities and that only a few individuals can identify and recognize specific opportunities in the market. The process of finding opportunities also depends on the individual's ability and discovery (Stevenson \& Gumpert, 1985). For example, people may miss opportunities due to a lack of cognitive ability to change external environments (Stevenson \& Gumpert, 1985). Only those who recognize and value the existence of opportunity can benefit from new opportunities (Ardichvili et al., 2003a, b; Shane \& Venkataraman, 2000). Opportunity recognition is an early step in transforming value into a business concept that creates value and generates revenue and distinguishes it from the aggressive stages of detailed assessment and development of recognized opportunities and potential economic value. The focus of the new venture business is also an innovative opportunity to create new opportunities rather than merely expanding or repeating existing business models (Gaglio \& Katz, 2001). As a result, universities need to make use of a variety of initiatives to educate students to recognize innovative opportunities. Therefore, entrepreneurship education aimed at a new opportunity recognition should be able to provide learning opportunities based on various theories of favorable conditions for new business creation and the types of traits required for new ventures (Garavan \& O'Cinne'ide, 1994).

Based on these considerations, we also define opportunity recognition as the formation of beliefs that can be translated into actions in order to understand the signals of change (new information on new conditions) and respond to these changes. 


\section{Problem-solving ability and innovative behavior of education for students}

Problem-solving abilities have been proven to be one of the key factors for success in organizations and personal careers (Anderson \& Anderson 1995). Through decades of research data, organizations and schools have studied factors that affect improvement. Problem-solving abilities are defined in a number of prior studies, and problem-solving abilities in a volatile and sophisticated knowledge- and technology-based industry are an important ability to drive innovation and sustainable growth and development in the industry. Table 1 show the concept of problem solving ability defined in previous research.

There have been a number of previous studies, emphasis has been placed on the importance and meaning of rational problem-solving processes in order to improve problem-solving abilities, and research has focused on individual problem solving styles (Woodman et al., 1993; Scott \& Bruce, 1994). According to the personal innovation behavior model of Scott and Bruce (1994), climate has shown individual innovative behavior as a result of individuals signaling the organization's expectations of behavior and the potential consequences of action. Innovative organizations are, last but not least, equipment, facilities and time, including the direction of creativity and innovative change (Kanter, 1983; Siegel \& Kaemmerer, 1978) Proper supply of such resources is important to innovation (Amabile, 1988; Van de Ven \& Angle, 1989; Dubickis \& GaileSarkane, 2017). Based on a study of Koestler's (1964) creative thinking, Jabri conceptualized a problem-solving style consisting of two independent thinking styles. He uses a structured problem-solving styles that is based on associative thinking, follows a set of rules, resolves reasonably logically, and uses an intuitive problem-solving ability that focuses on problem-solving, not tied to existing rules with multiple ideas. Intuitive problem solving styles tend to process information from different paradigms simultaneously. It is therefore more likely to create new problem solutions as possible (Isaksen, 1987; Kirton, 1976). However, style assessment is not desirable because the style of problem solving affects style differently depending on the individual problemsolving situations (Scott \& Bruce, 1994). We are proposing a role for the University to encourage innovative behavior based on the individuality of our students in order to recognize new opportunities through education about Scott and Bruce's innovative behavioral models and diverse entrepreneurship education approaches. And involvement of resources, such as entrepreneurship awareness programs, ultimately leads to the identification of individual characteristics and innovation. In addition, current Korean entrepreneurship education is mainly focused on cognitive learning to improve problem solving ability, and one aspect of cognitive learning plays an important role in

Table 1 Definition of problem solving

\begin{tabular}{ll}
\hline Publication & Definition \\
\hline Spivack et al. (1976) & $\begin{array}{l}\text { The ability to discover and create technologies and methods that can maximize } \\
\text { new and diverse problems in everyday interpersonal relationships }\end{array}$ \\
$\begin{array}{ll}\text { D'zurilla and Nezu (1990) } & \begin{array}{l}\text { A cognitive, emotional, and behavioral process that attempts to find the best } \\
\text { effective response when an individual has a specific problem in their daily lives }\end{array} \\
\text { Stevenson and Jarillo (1990) } & \text { Basic entrepreneurial skill } \\
\text { Warner (2002) } & \text { The ability to create the best solutions to problems while working. } \\
\text { Shane (2003) } & \text { The ability to identify opportunities with new information, such as puzzles. }\end{array}$
\end{tabular}


learning process of new venture firms. This study has a more direct focus on behavior learning such as team-based learning.

\section{Hypothesis development}

\section{Problem-solving ability and innovative behavior}

Problem solving is to discover knowledge and skills that reach the target country by interfering with a set of processes and goals where the solution is unknown, unfamiliar, or reaching a new state of goal (Jonassen, 2004; Inkinen, 2015). There are various approaches to solve this problem. To solve problems and improve problem solving with a successful solution experience, you should adopt the method that best suits your problem solution. You need to select the appropriate inputs for the solution elements and a flexible process structure. Problem solving ability has been recognized as a key element of innovative behavior in responding to rapid changes with the ability to find various alternatives and predict outcomes from these alternatives to maximize positive results, minimize negative consequences, and select solutions to problems (Barron \& Harrington, 1981; Jabri, 1991; Kirton, 1976). We pose the following hypotheses:

Hypothesis 1: Individual problem-solving ability has an effect on the innovative behavior of students.

\section{Innovative behavior and opportunity recognition}

Innovation involves introducing ideas from outside the organization, through creative processes, and linking these ideas to products or processes. Many scholars studying innovation recognize that designing ideas is only one step in the innovation process (Kanter, 1988). Innovation is changing at the organizational or individual level. Kanter, Scott and Bruce defined personal innovation. In other words, an innovation act starts with recognition of a problem, adoption of a new idea, or creation of a solution, and an individual with an innovative tendency wants to create a realistically realizable group with the sympathy of such an idea. Innovative individuals create prototypes for innovations that enable ideas to be realized specifically with goods or services and become productive use and social day merchandising. According to previous studies, opportunity perception can be seen as an individual's corporate strategy that focuses on the perception and exploitation of individuals about potential business ideas and opportunities and finds resources to create innovative outcomes (Manev et al., 2005). New Venture Ideas (NVI) are imaginary combinations of product/service offerings; potential markets or users, and means of bringing these offerings into existence (Davidsson, 2015). From the viewpoint of a potential entrepreneur like a university student, entrepreneurship starts with an idea. This process continues with a range of practices including attractiveness and feasibility of an idea, gathering information to minimize value-related uncertainty and possibility and perhaps the main idea's conformity ratio in terms of newly discovered needs (Hayton \& Cholakova, 2012). Earlier we proposed that the program as a whole increases the students' innovative behavior and that innovative performance is the new venture ideas. Since it is logical to assume that the relationship between innovative behavior and opportunity recognition. We pose the following hypotheses: 
Hypothesis 2: Innovative behavior will be a more potent inducer of opportunity recognition.

Problem-solving ability and opportunity recognition

Among the many factors influencing opportunity perception, the problems that arise in the fourth industry, the knowledge-based industry of the twenty-first century, are unpredictable and unstructured; they cannot be solved with existing solutions and require creative problem-solving skills. In order to determine how to solve problem situations that are different from the current situation and have unknown results, problems are solved through the process of adjusting previous experience, knowledge, and intuition (Charles \& Lester, 1982). Experience, knowledge, and intuition are applied simultaneously to a single problem, not individually or collectively, and the intellectual and creative results that can be quickly and effectively solved in problem solving are seen as problem solving abilities (Ardichvili et al., 2003a, b). Empirical studies of problemsolving abilities and opportunity perceptions have provided strong evidence that there is a positive relationship between theoretical integrative processes and corporate opportunity recognition (Ucbasaran et al., 2009). Therefore, we hypothesized that:

Hypothesis 3: Problem solving ability has an effect on the opportunity recognition.

\section{Methods}

The respondents for this study were randomly selected from three universities in Korea. Most of the respondents in this study were Korean university students who experienced team-based learning during behavioral learning through entrepreneurship education. Since then, we have been guided by two main criteria when choosing these universities. First, students who take entrepreneurship courses are critical to their innovation behavior. This led us to realize that innovative behavior is an important factor in an individual's survival and growth. The second is that the parallel process of theoretical and behavioral learning is highly satisfied. A pilot study was conducted to verify the reliability and validity of the research measurements with 28 students at a university. The results of the pilot study showed high clarity and reliability (Cronbach 's alphas were all above 0.70 ) of the research measurements. The sample of the pilot study was not incorporated in the present study.

\section{Sample}

This study was conducted in a four - year undergraduate course (various majors) that took entrepreneurship courses in Korea university programs. Students in this course have a mix of students who have previously experienced entrepreneurship and those who have not. During the course, students were taught the theoretical lessons for 8 weeks and the team for the 8 weeks. The questionnaire was administered during the last week of the course.

The data were analyzed from 203 participants, out of a total of 209, of which 7 were not appropriate. Of the 203 participants, 27\% were female and $73 \%$ were male and the grade distribution was $3 \%$ for freshmen, $12 \%$ for grade $2,26 \%$ for grade 2 , and $59 \%$ for grade 2 . The main distribution is $26 \%$ in social science, $16 \%$ in business and economics, $39 \%$ in engineering, $11 \%$ in music and athletics and $7 \%$ in others (see Table 2). 
Table 2 Sample demographics of this study

\begin{tabular}{lll}
\hline & Number & Percentage (\%) \\
\hline Grade & 6 & $3 \%$ \\
Freshman & 25 & $12 \%$ \\
Sophomore & 52 & $26 \%$ \\
Junior & 120 & $59 \%$ \\
Senior & & \\
Gender & 54 & $27 \%$ \\
Female & 149 & $73 \%$ \\
Male & & \\
Major & 53 & $26 \%$ \\
Social sciences & 33 & $16 \%$ \\
Business \& Economic & 79 & $39 \%$ \\
Engineering & 23 & $11 \%$ \\
Music and physical education & 15 & $7 \%$ \\
Others & & \\
\hline
\end{tabular}

\section{Measurement}

The structure of the model was measured by questionnaires (problem-solving ability, innovation behavior and opportunity recognition questionnaire) consisting of the scale taken from questionnaires verified in previous studies. Tool selection was performed on two criteria. First, the selected tool should measure the same structure (ie, the original measured structure had to be conceptually identical to the way the structure was defined in this study model). Secondly, the psychometric qualities of the instrument for the student had to be high.

Assessment of the factors was carried out through principal component analyses (varimax rotation with eigenvalues of 1.0 or above) of the scales connected to the same level of the model to confirm the uniqueness of the scales with respect to each other. This was supplemented by the computation of the internal consistency reliability of the scales (Cronbach's $\alpha$ ). These analyses were executed using the individual participants' responses (Nunnally \& Bernstein, 1994).

Problem- solving ability was measured on a 7 -point Likert-scale ( 1 = 'completely disagree'; 7 = 'completely agree'). Jabri (1991) used a measurement tool to measure individual problem solving ability.

Innovative behavior was measured on a 7-point Likert-scale ( 1 = 'completely disagree'; 7 = 'completely agree'). In order to measure innovation behavior, we modified the questionnaire items to fit the intention of this study among the questionnaire items used by Scott and Bruce (1994) and Kim and Rho (2010).

Opportunity recognition was measured on a 7 -point Likert-scale $(1=$ 'completely disagree'; 7 = 'completely agree'). In order to measure opportunity recognition, we modified the questionnaire items to fit the intention of this study among the questionnaire items used by Kim and Rho (2010).

\section{Methods of analysis}

The first two parts of the analysis were primarily based on (multiple) regression analyses. The last part of the analysis was informed through the path analyses. The 
adequacy of the models was assessed by AMOS 18(Arbuckle \& Wothke, 2003). Models were all tested with standardized coefficients obtained from the Principal Component Analysis. To ascertain the model fit, we analyzed the comparative fit index (CFI), the normed fit index (NFI), the Root Mean Square Err of Approximation (RMSEA), the standardized root mean square residual (SRMR) and the chi-square test statistic.

\section{Result}

Reliability and validity are essential psychometrics to be reported. The first step to evaluate those aspects was to use the Cronbach's alpha and the composite reliability to test reliability of the proposed scales. The usual threshold level is 0.7 for newly developed measures (Fornell and Larcker, 1981). Values range from 0.69 to 0.79 in the case of Cronbach's alpha, and from 0.85 to 0.92 in the case of composite reliability (see Table 3). Therefore, these scales may be considered as reliable. Next, we estimated the research model, displayed in Fig. 1, using structural equation modeling (SEM) and AMOS 18 (Arbuckle \& Wothke, 2003). Our analysis revealed an adequate measurement model with high factor loadings for all the items on the expected factors and communalities of each item exceeding 0.50. We discuss three fit indices that are generally considered as important (Hu \& Bentler, 1998). First, the CFI-value represents the overall difference between observed and predicted correlations. A value of 0.04 which is situated well below the cut-off value of 0.08 , suggests that the hypothesized model resembles the actual correlations. Secondly, Bentler's CFI (comparative fit index) greater

Table 3 Reliability and validity Analysis

\begin{tabular}{|c|c|c|c|c|c|c|c|}
\hline Item & Factors & $\begin{array}{l}\text { Standardized } \\
\text { loading }\end{array}$ & $\begin{array}{l}\text { Eigen } \\
\text { Value }\end{array}$ & $\begin{array}{l}\text { Cumulative } \\
(\%)\end{array}$ & Cronbach's a & AVE & C.R. \\
\hline \multirow{4}{*}{$\begin{array}{l}\text { Innovative } \\
\text { behavior }\end{array}$} & Innovative behavior 1 & $.713^{* * *}$ & \multirow[t]{4}{*}{3.203} & \multirow[t]{4}{*}{50.687} & \multirow[t]{4}{*}{0.854} & \multirow[t]{4}{*}{0.521} & \multirow[t]{4}{*}{0.812} \\
\hline & Innovative behavior 2 & $.825^{* * *}$ & & & & & \\
\hline & Innovative behavior 3 & $.705^{* * *}$ & & & & & \\
\hline & Innovative behavior 4 & $.832^{* * *}$ & & & & & \\
\hline \multirow[t]{6}{*}{$\begin{array}{l}\text { Opportunity } \\
\text { recognition }\end{array}$} & $\begin{array}{l}\text { Opportunity } \\
\text { recognition } 6\end{array}$ & $.743^{* * *}$ & \multirow[t]{6}{*}{3.893} & \multirow[t]{6}{*}{27.890} & \multirow[t]{6}{*}{0.916} & \multirow[t]{6}{*}{0.537} & \multirow[t]{6}{*}{0.874} \\
\hline & $\begin{array}{l}\text { Opportunity } \\
\text { recognition } 5\end{array}$ & $.804^{* * *}$ & & & & & \\
\hline & $\begin{array}{l}\text { Opportunity } \\
\text { recognition } 4\end{array}$ & $.823^{* * *}$ & & & & & \\
\hline & $\begin{array}{l}\text { Opportunity } \\
\text { recognition } 1\end{array}$ & $.884^{* * *}$ & & & & & \\
\hline & $\begin{array}{l}\text { Opportunity } \\
\text { recognition } 3\end{array}$ & $.804^{* * *}$ & & & & & \\
\hline & $\begin{array}{l}\text { Opportunity } \\
\text { recognition } 2\end{array}$ & $.780^{* * *}$ & & & & & \\
\hline \multirow[t]{4}{*}{ Problem-solving ability } & $\begin{array}{l}\text { Problem-solving } \\
\text { ability } 1\end{array}$ & $.819^{* * *}$ & \multirow[t]{4}{*}{3.041} & \multirow[t]{4}{*}{72.410} & \multirow[t]{4}{*}{0.873} & \multirow[t]{4}{*}{0.524} & \multirow[t]{4}{*}{0.813} \\
\hline & $\begin{array}{l}\text { Problem-solving } \\
\text { ability } 2\end{array}$ & $.684^{* * *}$ & & & & & \\
\hline & $\begin{array}{l}\text { Problem-solving } \\
\text { ability } 3\end{array}$ & $.884^{* * *}$ & & & & & \\
\hline & $\begin{array}{l}\text { Problem-solving } \\
\text { ability } 4\end{array}$ & $.807^{* * *}$ & & & & & \\
\hline
\end{tabular}

$\mathrm{N}=203$. Pearson Correlations (2-tiled) ${ }^{*} \mathrm{p}<.05,{ }^{* *} \mathrm{p}<.01,{ }^{* * *} \mathrm{p}<.001$ 


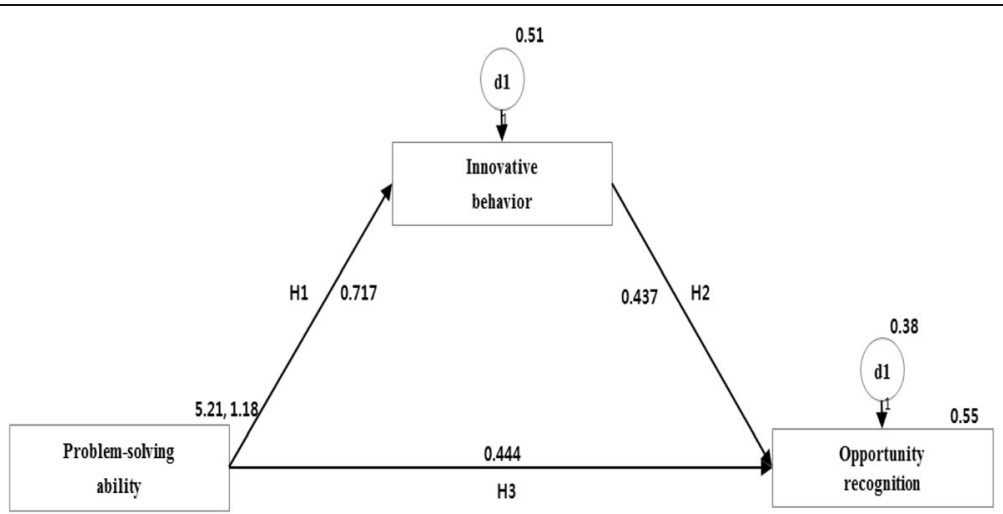

Fig. 1 Analysis of mediation effect

than 0.90 and 0.95 which is above the cut-off of 0.90 (Schumacker \& Lomax, 1996). Thirdly, NFI greater greater than 0.90 and 0.95 which is above the cut-off of 0.90 (Schumacker \& Lomax, 1996). Fourthly, the standardized root mean square residual (SRMR) value of 0.0392 which is situated well below the cut-off value of $0.05(\mathrm{Hu} \&$ Bentler, 1998), and the chi-square value of 3581.622 which is situated well below the cut-off value of 0.0005 . Finally, the RMSEA (root mean square error of approximation) equals 0.04 with a $90 \%$ confidence interval between 0.03 and 0.05 .

The value and confidence interval are situated over but below the cut-off value of 0.1 which suggests not a great but a good fit. Factor analysis was verified by factor analysis using principal component analysis and only factors with an eigenvalue of 1 or more by orthogonal rotation method were selected. Factor loading was considered to be significant at 0.5 or more (Hair et al., 2006a, b). As a result of the analysis, cumulative explanation for $72.4 \%$ of the total variance. Confirmatory factor analysis thus supported the differentiation of the three components Also we tested the confirmatory validity of the construct by testing whether the structural linkage of each square is greater than the mean variance extraction (AVE) of each structure. The AVE ranged from 0.52 to 0.53, reaching the recommended level of .50 for both Fornell and Larcker (1981). Therefore, all constructs showed sufficient convergent validity (see Table 3 ).

As shown in Table 4, the AVE value of each variable has a higher value than that of other factors. Therefore, the discriminant validity of the proposed model can be judged as appropriate.

Means, standard deviations, and correlations among the study variables are shown in Table 5.

The mean scores for the conceptual model were as follows for problem-solving ability (MD. 5.20, SD.1.08), innovative behavior (MD.5.20, SD.1.03), and opportunity recognition (MD. 5.14, SD. 1.06) conditions. The means of problem-solving ability, innovative

Table 4 Reliability and validity Analysis

\begin{tabular}{llll}
\hline Variable & 1 & 2 & 3 \\
\hline Problem-solving ability & 0.524 & & \\
Innovative behavior & 0.224 & 0.521 & 0.537 \\
Opportunity recognition & 0.174 & 0.261 & .
\end{tabular}


Table 5 Descriptive statistics and Inter-correlation matrix

\begin{tabular}{llllll}
\hline Variable & Means & SD & 1 & 2 & 3 \\
\hline Problem-solving ability & 5.6610 & 1.10382 & 1 & & \\
Innovative behavior & 5.3016 & 1.27055 & $.473^{* *}$ & 1 & \\
Opportunity recognition & 5.2016 & 1.26055 & $.417^{* *}$ & $.511^{* *}$ & 1 \\
\hline
\end{tabular}

$\mathrm{N}=$ 203. Pearson Correlations (2-tiled) ${ }^{*} \mathrm{p}<.05,{ }^{* *} \mathrm{p}<.01,{ }^{* * *} \mathrm{p}<.001$

behavior, and opportunity recognition were high. Furthermore, those variables correlated positively with each other.

Figure 1 showed that all paths and their significance levels are presented in Table 6. The path between the latent variables problem-solving ability and innovative behavior was significant ( $p, 0.001$ ), consistent with Hypotheses 1. In addition, there was innovative behavior and opportunity recognition (p, 0.01), this result provide empirical support for Hypothesis 2.

H3 proposed that Problem-solving ability is positively related to opportunity recognition. The results of the correlation analysis: The coefficient of problem solving and opportunity perception weakened from .717 to .444 , but it is still partly mediated because it is still significant $\left(C . R=7.604^{* * *}\right)$. This supports H3 (see Table 6).

In order to verify the significance of the indirect effect, the bootstrapping must be performed in AMOS, and the actual significance test should be identified using twotailed significance. As a result, the significance of indirect effect is $0.04(p<0.05)$, which is statistically significant (see Table 7).

\section{Discussion and conclusion}

We have tried to demonstrate the effects of behavior and its significance by differentiating from the general curriculum emphasizing cognitive effects as a model of problem solving ability emerging as innovative behavior through opportunity of university entrepreneurship education.. This supports the premise that entrepreneurship education can improve opportunities or processes through behavioral learning. The results of this study support the role of entrepreneurship education in creating opportunities for innovative behavior and problem solving abilities. Entrepreneurship education should provide different types of learning for new opportunities and focus on what is manifested in behavior.

In addition, based on previous research, we propose whether the following contents are well followed and whether it is effective. First, the emergence of innovative behavior in problem-solving abilities increases as the cognitive diversity of students with diverse majors and diverse backgrounds increases. Second, the more entrepreneurial learning

Table 6 Path analysis results for the research model

\begin{tabular}{|c|c|c|c|c|c|c|}
\hline Hypothesis & Path & $\begin{array}{l}\text { Regression } \\
\text { Weights }\end{array}$ & $\begin{array}{l}\text { Standardized } \\
\text { Regression Weights }\end{array}$ & S.E. & C.R. & Result \\
\hline $\mathrm{H1}$ & $\begin{array}{l}\text { Innovative behavior } \\
<- \text { Problem-solving ability }\end{array}$ & .680 & .717 & .047 & $14.615^{* * *}$ & Accept \\
\hline $\mathrm{H} 2$ & $\begin{array}{l}\text { Opportunity recognition } \\
<- \text { Innovative behavior }\end{array}$ & .449 & .437 & .060 & $7.479^{* * *}$ & Accept \\
\hline $\mathrm{H} 3$ & $\begin{array}{l}\text { Opportunity recognition } \\
<- \text { Problem-solving ability }\end{array}$ & .434 & .444 & .057 & $7.604^{* * *}$ & Accept \\
\hline
\end{tabular}

$N=203 .{ }^{*} p<.05,{ }^{* *} p<.01,{ }^{* * *} p<.001$ 
Table 7 Indirect effect analysis results for the research model

\begin{tabular}{llll}
\hline Path & Direct effect & Indirect effect & Total effect \\
\hline Opportunity recognition $<-$ Problem-solving ability & 0.444 & $0.777 \times 0.437=.340^{*}$ & 0.784 \\
\hline $\mathrm{N}=203 .{ }^{*} \mathrm{p}<.05,{ }^{* *} \mathrm{p}<.01,{ }^{* * *} \boldsymbol{p}<.001$ & &
\end{tabular}

experiences, the greater the chance of new opportunities. Third, it is necessary to investigate students' problem solving style and problem-solving ability first, and then a teaching strategy based on this combination of systematic and effective theory and practice is needed. Of course, as demonstrated by many studies, it may be easier to enhance the effectiveness of opportunity recognition through cognitive learning. This is because it emphasizes the achievement of knowledge and understanding with acquiring skills and competence. This process, however, is not enough for entrepreneurship education. However, we do not support full team-based behavioral learning in the class designed by Michaelsen and Sweet (2008). As with the results of this study, problem solving ability is positively related to opportunity perception directly. As previously demonstrated in previous studies, problem solving ability can be enhanced by cognitive learning (Anderson et al., 2001; Charles \& Lester, 1982).

Therefore, it has been demonstrated that it is more efficient to balance a certain level of cognitive learning and behavior learning in consideration of the level of students in a course. Also this study satisfies the need for empirical research by Lumpkin and Lichtenstein (2005) and Robinson et al. (2016) and others. This will help to improve understanding of how entrepreneurship training is linked to various learning models and their effectiveness and to design better courses for the future. Finally, this study sought to provide an awareness of entrepreneurship education as the best curriculum for solutions that evolved into innovative behaviors that create new values and ultimately represent new opportunities. This study shows that it can positively influence the social effect of creating new value, that is, not only the cognitive effect of general pedagogy, but also the innovation behavior. By providing this awareness, we have laid the groundwork for empirical research on entrepreneurship education in order to create more opportunities for prospective students in education through education and to expand their capabilities.

\section{Limitation and future research}

Indeed, the concepts presented here and the limitations of this study have important implications that can fruitfully be addressed in future research. First, we selected a sample of college students taking entrepreneurship training. However, since it is not the whole of Korean university students, it is difficult to extend the research results to all college students in Korea. Second, there is no precedent research on the role of innovation behavior as intermedia in college students. Therefore, we were forced to proceed as an exploratory study.

The ability to recognize opportunities can provide significant benefits that can remain firm and competitive in an ever-changing environment. Future research should therefore expand these insights and try to empirically test more ways in which entrepreneurship pedagogy teaches how learning methods can be integrated into venture creation and growth processes to help new process opportunities. By providing this study, we will help entrepreneurship education in the university to create more opportunities and expand the capacity of prospective members. 


\section{Publisher's Note}

Springer Nature remains neutral with regard to jurisdictional claims in published maps and institutional affiliations.

\section{Author details}

${ }^{1}$ Dept. of Technology Entrepreneurship (Graduate School), Dongguk University, 904 Chungmurogwn, Toegye-ro 36Gil, Jung-gu, Seoul 100-272, South Korea. ${ }^{2}$ Yonsei School of Business, Yonsei University, 50 Yonsei-ro, Seodaemun-gu, Seoul 120-749, South Korea.

Received: 12 September 2017 Accepted: 22 January 2018

Published online: 05 February 2018

\section{References}

Alvarez, S. A., \& Barney, J. B. (2005). How do entrepreneurs organize firms under conditions of uncertainty? Journal of Management, 31(5), 776-793.

Amabile, T. M. (1988). A model of creativity and innovation in organizations. Research in Organizational Behavior, 10(1), 123-167.

Ancona, D. G., \& Caldwell, D. F. (1992). Demography and design: Predictors of new product team performance. Organization Science, 3(3), 321-341.

Anderson, P. M., \& Anderson, P. M. (1995). Analysis of faulted power systems (Vol. 445). New York: IEEE press.

Anderson, L. W., Krathwohl, D. R., Airasian, P., Cruikshank, K., Mayer, R., Pintrich, P., \& Wittrock, M. (2001). A taxonomy for learning, teaching and assessing: A revision of Bloom's taxonomy. New York: Longman Publishing.

Arbuckle, J. L., \& Wothke, W. (2003). AMOS 5 user's guide. Chicago: Smallwaters.

Ardichvili, A., Cardozo, R., \& Ray, S. (2003a). A theory of entrepreneurial opportunity identification and development. Journal of Business Venturing, 18(1), 105-123.

Ardichvili, A., Cardozo, R., \& Ray, S. (2003b). A theory of entrepreneurial opportunity identification and development. Journal of Business Venturing, 18(1), 105-123.

Baron, R. A., \& Ensley, M. D. (2006). Opportunity recognition as the detection of meaningful patterns: Evidence from comparisons of novice and experienced entrepreneurs. Management Science, 52(9), 1331-1344.

Barron, F., \& Harrington, D. M. (1981). Creativity, intelligence, and personality. Annual review of psychology, 32(1), 439-476.

Casson, M. (1982). The entrepreneur: An economic theory. Lanham: Rowman \& Littlefield.

Charles, R., \& Lester, F. (1982). Teaching problem solving: What, why \& how. Palo Alto: Dale Seymour Publications.

Davidsson, P. (2015). Entrepreneurial opportunities and the entrepreneurship nexus: A re-conceptualization. Journal of Business Venturing, 30(5), 674-695.

Dubickis, M., \& Gaile-Sarkane, E. (2017). Transfer of know-how based on learning outcomes for development of open innovation. Journal of Open Innovation: Technology, market, and complexity, 3(1), 4.

Dyer, J. H., Gregersen, H. B., \& Christensen, C. (2008). Entrepreneur behaviors, opportunity recognition, and the origins of innovative ventures. Strategic Entrepreneurship Journal, 2(4), 317-338.

D'zurilla, T. J., \& Nezu, A. M. (1990). Development and preliminary evaluation of the social problem-solving inventory. Psychological Assessment: A Journal of Consulting and Clinical Psychology, 2(2), 156.

Fornell, C., \& Larcker, D. F. (1981). Evaluating structural equation models with unobservable variables and measurement error. Journal of Marketing Research, 39-50.

Gaglio, C. M., \& Katz, J. A. (2001). The psychological basis of opportunity identification: Entrepreneurial alertness. Small Business Economics, 16(2), 95-111.

Garavan, T. N., \& O'Cinneide, B. (1994). Entrepreneurship education and training programmes: A review and evaluationpart 1. Journal of European Industrial Training, 18(8), 3-12.

Gartner, W. B., \& Carter, N. M. (2003). Entrepreneurial behavior and firm organizing processes. In Handbook of entrepreneurship research (pp. 195-221). New Mexico: Springer US

Hair, E., Halle, T., Terry-Humen, E., Lavelle, B., \& Calkins, J. (2006a). Children's school readiness in the ECLS-K: Predictions to academic, health, and social outcomes in first grade. Early Childhood Research Quarterly, 21(4), 431-454.

Hair, J. F., Black, W. C., Babin, B. J., Anderson, R. E., \& Tatham, R. L. (2006b). Multivariate Data Analysis (6th ed.). Upper Saddle River: Pearson Education, Inc.

Hayton, J. C., \& Cholakova, M. (2012). The role of affect in the creation and intentional pursuit of entrepreneurial ideas. Entrepreneurship Theory and Practice, 36(1), 41-68.

Hu, L. T., \& Bentler, P. M. (1998). Fit indices in covariance structure modeling: Sensitivity to underparameterized model misspecification. Psychological Methods, 3(4), 424

Inkinen, T. (2015). Reflections on the innovative city: Examining three innovative locations in a knowledge bases framework. Journal of Open Innovation: Technolodgy, market. Complexity, 1(1), 8.

Isaksen, S. G. (1987). Frontiers of creativity research: Beyond the basics. Bearly Ltd.

Jabri, M. M. (1991). The development of conceptually independent subscales in the measurement of modes of problem solving. Educational and Psychological Measurement, 51(4), 975-983.

Jonassen, D. H. (2004). Learning to solve problems: An instructional design quide (Vol. 6). Hoboken: John Wiley \& Sons,

Kanter, R. M. (1983). The change masters: Binnovation and entrepreneturship in the American corporation. Touchstone Book.

Kanter, R. M. (1988). Three tiers for innovation research. Communication Research, 15(5), 509-523.

Kim, H. C., Song, C. H., \& An, B. R. (2016). A study on effects of personal characteristics on start-up opportunity and entrepreneurial intention of start-up. Korean Management Consulting review, 16(3), 75-87.

Kim, S. A., Ryoo, H. Y., \& Ahn, H. J. (2017). Student customized creative education model based on open innovation. Journal of Open Innovation: Technology, Market, and Complexity, 3(1), 6.

Kim, T. H., \& Roh, J. H. (2010). A Study of the Impact of Public Service Motivation on Innovative Behavior of Organizational Members. Korean Journal of Public Administration, 48(3).

Kirton, M. (1976). Adaptors and innovators: A description and measure. Journal of Applied Psychology, 61(5), 622. 
Kirzner, I. M. (1997). Entrepreneurial discovery and the competitive market process: An Austrian approach. Journal of Economic Literature, 35(1), 60-85.

Ko, S., \& Butler, J. E. (2003). Alertness, bisociative thinking ability, and discovery of entrepreneurial opportunities in Asian hi-tech firms.

Koestler, A. (1964). The act of creation: A study of the conscious and unconscious processes of humor, scientific discovery and art.

Lumpkin, G. T., \& Dess, G. G. (2004). E-Business Strategies and Internet Business Models: How the Internet Adds Value. Organizational Dynamics, 33(2), 161-173.

Lumpkin, G. T., \& Lichtenstein, B. B. (2005). The role of organizational learning in the opportunity-recognition process. Entrepreneurship Theory and Practice, 29(4), 451-472.

Manev, I. M., Gyoshev, B. S., \& Manolova, T. S. (2005). The role of human and social capital and entrepreneurial orientation for small business performance in a transitional economy. International Journal of Entrepreneurship and Innovation Management, 5(3-4), 298-318.

Michaelsen, L. K., \& Sweet, M. (2008). The essential elements of team-based learning. New directions for teaching and learning, 2008(116), 7-27.

Nunnally, J. C., \& Bernstein, I. H. (1994). Validity. Psychometric theory, 99-132.

Paine, J. B., \& Organ, D. W. (2000). The cultural matrix of organizational citizenship behavior: Some preliminary conceptual and empirical observations. Human Resource Management Review, 10(1), 45-59.

Robinson, S., Neergaard, H., Tanggaard, L., \& Krueger, N. F. (2016). New horizons in entrepreneurship education: from teacher-led to student-centered learning. Education+ Training, 58(7/8), 661-683.

Schumacker, R. E., \& Lomax, R. G. (1996). A beginner's guide to structural equation modeling. Mahwah: Laurence Erlbaum Google Scholar.

Scott, S. G., \& Bruce, R. A. (1994). Determinants of innovative behavior: A path model of individual innovation in the workplace. Academy of Management Journal, 37(3), 580-607.

Shane, S. A. (2003). A general theory of entrepreneurship: The individual-opportunity nexus. Cheltenham: Edward Elgar Publishing.

Shane, S., \& Venkataraman, S. (2000). The promise of entrepreneurship as a field of research. Academy of Management Review, 25(1), 217-226.

Siegel, S. M., \& Kaemmerer, W. F. (1978). Measuring the perceived support for innovation in organizations. Journal of Applied Psychology, 63(5), 553-562.

Spivack, G., Platt, J. J., \& Shure, M. B. (1976). The problem-solving approach to adjustment. San Francisco: Jossey-Bass.

Stevenson, H., \& Gumpert, D. (1985). The heart of entrepreneurship.

Stevenson, H. H. \& J. C. Jarillo (1990). 'A paradigm of entrepreneurship: Entrepreneurial management', Strategic Management Journal, 11, pp. 17-27.

Ucbasaran, D., Westhead, P., \& Wright, M. (2009). The extent and nature of opportunity identification by experienced entrepreneurs. Journal of Business Venturing, 24(2), 99-115.

Van de Ven, A. H., \& Angle, H. L. (1989). Suggestions for managing the innovation journey (No. 9). Strategic Management Research Center, University of Minnesota.

Venkataraman, S. (1997). The distinctive domain of entrepreneurship research. Advances in entrepreneurship, firm emergence and growth, 3(1), 119-138.

Venkataraman, S., \& Sarasvathy, S. D. (2001). Strategy and entrepreneurship: Outlines of an untold story.

Warner, M. (2002). Publics and counterpublics. Public Culture, 14(1), 49-90.

Woodman, R. W., Sawyer, J. E., \& Griffin, R. W. (1993). Toward a theory of organizational creativity. Academy of Management Review, 18(2), 293-321.

\section{Submit your manuscript to a SpringerOpen ${ }^{\circ}$ journal and benefit from:}

- Convenient online submission

- Rigorous peer review

Open access: articles freely available online

High visibility within the field

Retaining the copyright to your article 